\title{
Huda Zoghbi: Taking genetic inquiry to the next level
}

\author{
BY RACHEL ZAMZOW
}

25 JUNE 2021

\section{Listen to this story:}

\section{https://www.spectrumnews.org/wp-}

content/uploads/2021/06/audio-1 c73a790-bd20-463a-8499-847b220da723-encodings.mp3

Most mornings, Huda Zoghbi, 67, climbs a glass-encased, curling staircase to reach her lab on the top and $13^{\text {th }}$ floor of the Jan and Dan Duncan Neurological Research Institute in Houston, Texas. The twisting glass tower, which she designed with a team of architects, echoes the double helix of DNA - a structure that has been central to her career-long quest to uncover genes underlying neurological conditions.

As the institute's director - and as a scientist - she is known for going beyond the standard job description. Genetics researchers often cast a wide net and sequence thousands of genes at a time. But in her prolific career, Zoghbi has focused on a handful of genes, methodically building up an understanding of their function one careful step at a time.

Thanks to that approach, Zoghbi has made a number of landmark discoveries, including identifying the genetic roots of Rett syndrome, an autism-related condition that primarily affects girls, as well as the genetic mutations that spur spinocerebellar ataxia, a degenerative motor condition. She has authored more than 350 journal articles.

Her accomplishments have earned her almost every major biology and neuroscience research award, including the prestigious Breakthrough Prize in 2017 and the Brain Prize in 2020. "She's clearly the international leader in the field," said the late Stephen Warren, professor of human genetics at Emory University in Atlanta, Georgia.

Zoghbi never set out to lead a large research center, she says - her heart is in the lab. That said, she has excelled at it: Since the institute's inception in 2010, it has grown to host more than 200 


\section{Spectrum | Autism Research News}

https://www.spectrumnews.org

scientists and fostered more than 70 new disease gene discoveries.

Part of that success may be due to the high expectations she sets for her trainees. They work long hours in what some call "the lab that never sleeps," says Vincenzo Alessandro Gennarino, a former postdoctoral fellow in the lab, now assistant professor of genetics and development, pediatrics and neurology at Columbia University. But many say she is also endlessly empathetic and caring toward her 'lab family,' as she describes it. "She really kind of sees them as her scientific children in a way," says her son, Anthony Zoghbi, assistant professor of clinical psychiatry at Columbia.

For more than a decade now, this family has worked toward turning the deep biological mechanisms they have uncovered into treatment targets for Rett syndrome and other autismrelated conditions. Finding effective therapeutics for such complex conditions is a tall order, Warren said. "But she's got good model systems, good ideas, and she attracts very talented people in her lab, so I think she has a crack at it."

\section{From clinic to lab:}

Zoghbi grew up in the vibrant city of Beirut, Lebanon, in the 1950s and '60s. Her father filled the family's home with books, which fueled an early passion for Arabic and English literature. She considered studying English literature when she entered the American University of Beirut in 1973, but she switched to biology, swayed by her mother, who saw her talent for the sciences. This path led Zoghbi to medical school at the same institution.

During her first few months of medical training in 1975, the Lebanese Civil War that had erupted earlier that year escalated. Constant bombings made it too dangerous to commute, so Zoghbi and her 62 classmates took shelter on campus. She lived in a closet inside a women's bathroom until the school year ended.

When flying shrapnel injured her 16-year-old brother, Jamal, in the spring, Zoghbi's parents decided to send her and her younger siblings to live with their older sister in the United States for the summer. By mid-September, the war had only worsened, and Zoghbi scrambled to find a medical school that would accept a transfer student from another country.

Within weeks, she landed an interview at Meharry Medical College, a historically Black institution in Nashville, Tennessee, and started classes the next day. She spent the rest of the year catching up and feeling achingly homesick, she says, taking solace only in letters from William Zoghbi, a classmate she had started dating before she left Lebanon. "Those books were soaked with tears," Zoghbi says. "I literally cried my way through that year."

William - whom she says she admired for his captivatingly kind smile - joined her at Meharry the following year. They later married. (William Zoghbi is now chair of cardiology at Houston Methodist 


\section{Spectrum | Autism Research News}

https://www.spectrumnews.org

Hospital.)

Zoghbi sought a future in pediatric cardiology at the start of her residency at Houston's Baylor College of Medicine in 1979. "And then I rotated in neurology, and everything changed," she says. "I fell in love with neurology."

But her excitement wore off soon after she started a neurology fellowship in 1982. It was incredibly frustrating, Zoghbi says, to diagnose children with rare neurological conditions and be unable to provide their families with any information about a cause or hope for a treatment.

This helpless feeling came to a point in October the following year, when she encountered a little girl with a particularly devastating and puzzling condition: Ashley Fry, a 3-year-old girl with sparkling brown eyes, had developed typically for the first 18 months of her life but then suddenly started losing language skills and wringing her hands, rubbing her left hand over and over with her right.

"That pain was very tangible to me - like, to have a girl, she's healthy, and she's beautiful, and you're enjoying her, and then to see her robbed of that," Zoghbi says. "I felt that agony."

Zoghbi and her attending physicians diagnosed Ashley with Rett syndrome. Ashley was the first case diagnosed in Texas and among only a handful identified in the U.S. at the time. But a week later, Zoghbi found another case - a girl who arrived at a cerebral palsy clinic wringing her hands. Zoghbi pulled more charts from the clinic describing similar symptoms - a stark regression, intellectual disability, seizures and hand-wringing — and found a few more cases.

Soon Zoghbi and her colleagues started publishing papers on Rett syndrome, and children with suspected cases came in from all over the country. "One after the other they looked the same, and I was like, 'It has to be a gene,' and that's when I decided I'm going to go into research," Zoghbi says.

In 1984, she approached the renowned geneticist Arthur Beaudet at Baylor about doing a postdoctoral fellowship in his lab. She had collected blood samples from 200 children with Rett syndrome, and she wanted to try to find the gene underlying the condition. Zoghbi had virtually no laboratory experience, but "she was just extremely talented and bright and motivated," says Beaudet, now chief executive officer of the Houston-based prenatal genetic testing company Luna Genetics. "She was the kind of trainee every scientist hopes to encounter one day."

Beaudet took Zoghbi on but, to her disappointment, said she couldn't focus on Rett syndrome, which he deemed too difficult to trace genetically. Zoghbi agreed instead to study a family in Texas with spinocerebellar ataxia - work that later led to a groundbreaking co-discovery of the gene underlying a subtype of the condition. 


\section{Ruminating on Rett:}

Even as Zoghbi's spinocerebellar ataxia work accelerated, she continued thinking about Rett syndrome. Her urge to help grew even stronger when she had her first child, a daughter named Roula, in 1985. She did little experiments here and there, sometimes under the radar, searching for clues that the causative gene was on the X chromosome, or X-linked. If so, it would explain why all the cases she'd seen so far were girls. If a mutation disrupts a gene on the $X$ chromosome, girls, who have two Xs, still have a functioning copy. But boys, who have only one $\mathrm{X}$ chromosome, might not survive.

She was able to pursue her ideas further when she started her own lab at Baylor in 1988. With help from geneticist Uta Francke at Stanford University in California, Zoghbi and her team eventually ruled out more than two-thirds of the genes along the $X$ chromosome. That left hundreds of genes to explore, which they started sequencing one by one, taking about a year's worth of work each time. "Every gene was a labor of love," Zoghbi says.

Negative results piled up, and funding slowed. But Zoghbi kept at it, persistent as ever. Sometimes, during long weekends in the lab, her two children, Roula and Anthony, tagged along, peering into petri dishes or practicing pipetting while she worked.

One afternoon in August 1999, Zoghbi's phone rang just as she and her family were returning home from their annual summer trip to Lebanon. She raced to the phone, and on the other end was Ruthie Amir, a postdoctoral fellow in the lab.

"I think I found it," Amir said.

Poring over the data together at Zoghbi's house later that day, the pair saw that five girls with Rett syndrome all carried a spontaneous mutation in the same gene on the $\mathrm{X}$ chromosome. The gene, MECP2, encodes a protein known as methyl-CpG binding protein 2, which regulates the expression of thousands of other genes throughout the body and brain.

The team published their results two months later in Nature Genetics, 16 years after Zoghbi first met Ashley. Zoghbi invited Ashley and her family to the press conference announcing the discovery. She didn't have to explain why she was asking them to come to Houston, recalls Ashley's father, Clifford Fry. "I knew it in my heart that she had found the gene."

Zoghbi has meticulously probed the far-reaching effects of MECP2 ever since, tracking the results of removing the gene from different areas or cell types in the brain. Each of these 'conditional knockouts' has helped to account for a subset of Rett-related traits. Deleting MECP2 from the hypothalamus, for example, produces mice that eat uncontrollably and are aggressive and easily stressed, not unlike traits seen in boys with less severe mutations in MECP2. 


\section{Spectrum | Autism Research News}

https://www.spectrumnews.org

Knocking out MECP2 in inhibitory neurons recapitulates almost all the traits of Rett syndrome. The mice even clasp their forepaws repeatedly, which mirrors the girls' hand-wringing. And by removing MECP2 from each of two subtypes of inhibitory neurons, or from inhibitory versus excitatory cells, Zoghbi has demonstrated how the gene supports the function of whole brain circuits, not just individual neurons.

Zoghbi and her team also engineered mice with an extra copy of MECP2 to use as controls in Rett experiments. But the animals developed severe seizures, and about a third died prematurely. This unexpected result, published in 2004, showed that a surplus of MECP2 protein can be just as problematic as a deficiency. The following year, another team described some of the first cases of MECP2 duplication syndrome, which causes autism, intellectual disability and seizures - mostly in boys.

Zoghbi is particularly attached to her MECP2 duplication work because Tropical Storm Allison nearly washed it away. When the storm slammed into Houston in June 2001, it flooded the animal facility where some of Zoghbi's MECP2 duplication mice lived. Zoghbi and one of her graduate students suited up in waders and went searching with a flashlight through the chest-high water for any surviving mice. They found a lone survivor in a top rack of the cages. That mouse is the founder of one of the MECP2 duplication colonies the lab studies to this day.

"I learned a lesson from that," Zoghbi says. "Always go back and take a second look. You never know."

\section{Forging forward:}

Zoghbi holds a steady focus on finding what will truly help people with Rett syndrome and the other conditions she studies. "It's clear that her approach is not 'Okay, l've discovered the gene, l've done my job,"' says Michela Fagiolini, associate professor of neurology at Harvard University, who also studies Rett syndrome. And that drive is Zoghbi's true legacy: "She has built not just an empire in Texas but also created a school of thinking."

In one ongoing line of work, Zoghbi's team has used snippets of genetic material, called antisense oligonucleotides, to silence the extra MECP2 gene copy in duplication mice. A drug delivering these genetic strands reverses problems with movement, learning and memory in mice with two human copies of MECP2, suggesting that it might also be effective in people.

The key to these types of treatments, Zoghbi says, will be titrating the dosage of MECP2 expression so that it normalizes protein levels without tipping them too far in the direction of Rett syndrome. As such, Zoghbi is searching for biomarkers that signal when MECP2 levels have reached a 'safe zone.' 


\section{Spectrum | Autism Research News}

https://www.spectrumnews.org

Zoghbi has also worked with colleagues at Baylor to show that deep brain stimulation applied to the hippocampus improves learning and memory in a mouse model of Rett. They are exploring whether stimulating motor circuits can similarly ease motor deficits in the mice. And Zoghbi has also tried mimicking the effects of deep brain stimulation in the form of intensive behavioral training to activate some of the same circuits.

Training Rett mice on motor and memory tasks early in life postpones the onset of difficulties in these areas, according to results published in March. If the same holds true in human clinical trials, it would help build the case to offer genetic screening for Rett syndrome in newborns, Zoghbi says. "Let's give these girls the maximum opportunity, and let's hopefully delay the disease onset by a year or year and a half or two," until more effective genetic treatments become a reality, she says.

Zoghbi stopped working as a clinician a couple of years ago, but a photo of Ashley, now 41, sits on the windowsill in her office, reminding her of where it all started and what she's working toward.

When Ashley and her family are in town, Zoghbi sometimes meets them at their hotel, just to say hi to Ashley and give her a hug and a gift, such as an ornate purple and gold shawl.

Giving people like Ashley a chance to fully engage in their world is at the heart of Zoghbi's inexhaustible work ethic, says Laura Lavery, a postdoctoral associate who has worked with Zoghbi for the past seven years. "She's the most driven person l've ever met, and underlying all of that is really her love and empathy for humankind. She is just not going to stop until she figures out how to help."

Cite this article: https://doi.org/10.53053/CCKM6750 